\title{
HUBUNGAN PENGETAHUAN DAN KEMAMPUAN MENDISAIN ORNAMEN DENGAN HASIL BELAJAR MEMBATIK MOTIF ORNAMEN BATAK ANGKOLA MANDAILING SISWA KELAS X SMK KARYA BUNDA MEDAN
}

\author{
Siti Asyiah Siregar ${ }^{1 *}$, Sugito $^{2 *}$, Wahyu Tri Atmojo ${ }^{3 *}$ \\ Program Studi Pendidikan Seni Rupa Jurusan Seni Rupa Fakultas Bahasa dan Seni \\ Universitas Negeri Medan \\ Jl. Willem Iskandar Pasar V Medan Estate, Kec, Percut Sei Tuan, Kab. Deli Serdang, Kode Pos 20371 \\ Sumatera Utara. Indonesia \\ Email: sitiasiyahsiregar@gmail.com
}

\begin{abstract}
Abstrak
Penelitian ini dilakukan di SMK Karya Bunda Medan yang bertujuan untuk membuktikan apakah ada hubungan yang siknifikan antara hubungan pengetahuan ornamen dan kemampuan mendesain ornamen terhadap hasil belajar membatik motif ornamen Batak Angkola Mandailing. Populasi dalam penelitian ini adalah seluruh siswa kelas X SMK Karya Bunda Medan. Pengambilan sampel menggunakan teknik sampel jenuh sebanyak 19 orang dari kelas X. Penelitian ini menggunakan metode korelasional, yaitu penelitian ini mencari ada tidaknya hubungan antara pengetahuan dan kemampuan mendisain ornamen dengan hasil belajar membatik motif ornamen Batak Angkola Mandailing. Teknik Analisis data menggunakan korelasi ganda (R), Uji keberartian dengan formula F. Hasil temuan penelitian: $r x_{1} y=0,60, r x_{2} y=0,58$ dan $r x_{1} x_{2}=0,75$ menunjukkan bahwa terdapat hubungan pengetahuan dan kemampuan mendisain ornamen dengan hasil belajar membatik motif ornamen Batak Angkola Mandailing, yang dibuktikan dengan $\mathrm{F}_{\text {hitung }}=4,87$ untuk dk=n-k-1 = $16 \alpha=$ $0,05 \mathrm{~F}_{\text {tabel }}=3,63$ ternyata $\mathrm{F}_{\text {hitung }}>\mathrm{F}_{\text {tabel }}(4,87>3,63)$. Besar sumbangan (kontribusi) antara pengetahuan dan kemampuan mendisain ornamen dengan hasil belajar membatik motif ornamen Batak Angkola Mandailing diperoleh $\mathrm{r}^{2}=62 \%$ artinya bahwa $\mathrm{X}_{1}$, dan $\mathrm{X}_{2}$ memberikan kontribusi atau masukan (sumbangan) pada $\mathrm{Y}$ rata-rata $62 \%$, sisanya $38 \%$ dari variabel lain.
\end{abstract}

Kata Kunci: pengetahuan, mendisain, membatik, angkola, mandailing.

\begin{abstract}
This research was conducted at SMK Karya Bunda Medan which aims to prove whether there is a significant relationship between the relationship of ornamental knowledge and the ability to design ornaments to the learning outcomes of batik motifs of Angkola Mandailing Batak ornaments. The population in this study were all students of class X SMK Karya Bunda Medan. Sampling using saturated sample technique as many as 19 people from class X. This study uses a correlational method, namely this study looks for whether there is a relationship between knowledge and ability to design ornaments with the results of learning to batik Angkola Mandailing Batak ornament motifs. Data analysis technique uses multiple correlation $(R)$, significance test with formula $F$. The results of the study: $r x_{1} y=0,60, r x_{2} y=0,58$ and $r x_{1} x_{2}=0,75$ shows that there is a relationship between knowledge and ability to design ornaments with learning outcomes batik Angkola Batak ornament motifs Mandailing, which is proven by $F_{\text {count }}=4.87$ for $d k=n k-1=16 \alpha=0.05 F_{\text {table }}=3.63$, it turns out $F_{\text {count }}>F_{\text {table }}(4.87>3.63)$. The contribution between knowledge and ability to design ornaments with the results of learning to batik Angkola Mandailing Batak ornament motifs obtained $r^{2}=62 \%$ means $X_{1}$ and $X_{2}$ give contribution or input to the learning outcomes of $Y$ averaged $62 \%$, the remaining $38 \%$ from other variables.
\end{abstract}

Keywords: knowledge, design, make batik, angkola, mandailing.

\section{PENDAHULUAN}

Pendidikan merupakan kebutuhan yang sangat penting bagi manusia, karena mampu mencapai kemajuan di berbagai bidang kehidupan terutama dalam rangka peningkatan kualitas Sumber Daya Manusia (SDM).
Hal tersebut dilakukan untuk mencerdaskan kehidupan bangsa sesuai dengan tujuan Pendidikan Nasional. Dalam upaya mencerdaskan kehidupan bangsa, peran dunia pendidikan tidak dapat diabaikan begitu saja. 
SMK Karya Bunda Medan merupakan salah satu sekolah yang mengembangkan kreativitas melalui mata pelajaran muatan lokal. Muatan lokal (Mulok) merupakan matapelajaran yang bertujuan untuk mengasah kekreativitasan peserta didik dalam karya seni, salah satunya yaitu kerajinan membatik. Batik merupakan kain bergambar yang pembuatannya secara khusus dengan menuliskan atau menerapkan malam pada kain, kemudian pengolahannya diproses dengan cara tertentu yang memiliki kekhasan.

Menurut ibu kepala sekolah SMK Karya Bunda Medan Ibu Tyas Dwi Kristiningsih siswa kelas X SMK Karya Bunda Medan masih belum mahir dalam mendisain motif ornamen sehingga belum memenuhi unsur-unsur desain dalam ornamen. (Wawancara: Tyas Dwi Kristiningsih: Senin, 27 Agustus 2018: 09.00).

Salah satu indikator pendidikan berkualitas adalah perolehan hasil belajar yang maksimal oleh siswa, baik itu hasil belajar maupun kemampuan siswa dalam berkarya (Sardiman, 2010: 3). Akan tetapi, jika pengetahuan siswa terhadap materi yang sedang di pelajari kurang baik, maka perolehan hasil belajar siswa akan memperoleh hasil yang buruk pula.

Pengetahuan siswa dapat dilihat dari kecakapan peserta didik menguasai teori-teori yang berkaitan dengan membatik motif ornamen Batak Angkola Mandailing yang meliputi :Pengetahuan tentang jenisjenis motif ornamen Batak Angkola Mandailing, mengetahui bagaimana mendesain motif ornamen Batak Angkola Mandailing. pengetahuan alat dan bahan yang digunakan dalam proses pembuatan batik motif ornamen Batak Angkola Mandailing.

Kurangnya kemampuan siswa dalam mendesain motif ornamen dilihat dari hasil yang diambil saat studi pendahuluan, hasil test siswa menunjukkan 18 siswadari 21 siswa kelas X SMK Karya Bunda Medan mendapat nilai di bawah nilai KKM menunjukkan siswa masih belum menguasai pengetahuan tentang membatik motif ornamen batak angkola mandailing. Hal ini diduga karna kurangnya pengetahuan siswa tentang jenis dan motif ornamen Batak Angkola Mandailing.

Dengan belajar membatik motif ornamen Batak Angkola Mandailing kepada siswa kelas X SMK Karya Bunda Medan sebagai langkah awal untuk melestarikan identitas daerah yakni membatik motif ornamen Batak Angkola Mandailing.

\section{KAJIAN TEORI}

\section{Belajar}

Belajar adalah suatu proses usaha yang dilakukan seseorang untuk memperoleh suatu perubahan tingkah laku yang baru secara keseluruhan, sebagai hasil pengalamannya sendiri dalam interaksi dengan lingkungannya. Perubahan tersebut akan nyata dalam seluruh aspek tingkah laku seseorang, baik perubahan pada dirinya maupun dalam kehidupan sehari-hari", (Slameto, 2010:2).

Menurut Ratnawati (2006:206) "Prestasi adalah hasil yang telah dicapai, dilakukan atau dikerjakan oleh siswa pada jangka waktu tertentu dan dicatat dalam buku rapor sekolah".

Berdasarkan pendapat para ahli di atas, dapat disimpulkan bahwa belajar merupakan suatu proses untuk mendapatkan ilmu pengetahuan disertai adanya interaksi antara individu dengan individu lain maupun individu dengan lingkungannya sehingga terjadi perubahan tindakan atau perilaku pada diri individu dari semula tidak tahu menjadi tahu.

\section{Hasil Belajar}

"Hasil belajar merupakan bagian penting dalam proses pembelajaran. Sudjana (2014:45) mengemukakan bahwa, "Hasil belajar siswa pada hakikatnya adalah perubahan tingkah laku sebagai hasil belajar dalam pengertian yang lebih luas mencakup bidang kognitif, afektif, dan psikomotorik. Dalam proses belajar mengajar di sekolah saat ini, tipe hasil belajar kognitif lebih dominan jika dibandingkan dengan tipe hasil belajar bidang afektif dan psikomotoris".

Menurut Sardiman (2009:3) juga menyebutkan "Hasil belajar merupakan hasil dari suatu interaksi tindak belajar dan tindak mengajar. Dari sisi guru, tindak mengajar diakhiri dengan proses evaluasi hasil belajar. Dari sisi siswa, hasil belajar merupakan berakhirnya pengajaran dari puncak proses belajar".

Pendapat lain menurut Hamalik (2009:30), "Hasil belajar adalah terjadinya perubahan tingkah laku pada diri siswa yang dapat diamati dalam bentuk perubahan pengetahuan, sikap, dan ketrampilan. Perubahan tersebut diartikan adanya peningkatan dan pengembangan yang lebih baik dibanding sebelumnya. Perubahan yang timbul pada individu harus mengarah pada perubahan positif yang berupa kecakapan sikap, kebiasaan dan pengertian".

Kesimpulan dari hasil belajar adalah perubahan tingkah laku siswa dalam perubahan pengetahuan, sikap dan keterampilan serta pengetahuan dan 


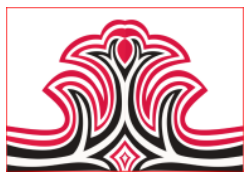

pengembangan sebelumnya.

\section{Ornamen}

Pengetahuan Ornamen dapat dilihat dari kecakapan peserta didik menguasai teori-teori yang berkaitan dengan membatik motif ornamen Batak Angkola Mandailing yang meliputi: pengetahuan tentang jenisjenis motif ornamen Batak Angkola Mandailing, mengetahuai bagai mana mendesai motif ornamen Batak Angkola Mandailing. pengetahuan alat dan bahan yang digunakan dalam proses pembuatan batik motif ornamen Batak Angkola Mandailing.

Menurut Sirait (1980:6) dalam bukunya yang berjudul Laporan Penelitian Pengumpulan dan Dokumentasi Ornamen Tradisional di Sumatera Utara "Istilah ragam hias berasal dari dua perkataan ragam dan hias yang berpadu menjadi satu pengertian pola. Dalam bahasa Ingris disebut ornament dan dalam bahasa Belanda dikatakan Siermotieven". Ragam hias atau ornamen itu sendiri terdiri dari berbagai jenis motifmotif itulah yang digunakan sebagai penghias sesuatu yang kita hiasi.Oleh karena itu motif adalah dasar untuk menghias sesuatu ornamen (Soepratno, 1997:11). Ornamen dimaksudkan untuk menghias sesuatu bidang atau benda, sehingga benda tersebut menjadi indah seperti yang kita lihat pada hiasan kulit buku, piagam, kain batik, tempat bunga dan barangbarang lainnya.

Semula ornamen-ornamen merupakan garis seperti: garis lurus, garis patah, garis miring, garis sejajar, garis lengkung, lingkaran, dan dan sebagainya yang kemudian berkembang menjadi bermacam-macam bentuk yang beraneka ragam coraknya.

\section{Desain Ornamen}

Desain diambil dari kata design (bhs. Inggris), istilah ini dapat diartikan sebagai merancang. Dilingkungan akademik. Bruce Archer dalam buku sejarah dan perkembangan desain \& dunia kesenian di Indonesia Mengatakan pengertian desain adalah:

Desain is a one from of human physical and spiritual needs that are described through various fields, expertise and knowledge that reflects attention to appreciation and adaptation to the surroundings, especially those relating to the form, composition, mesning, snd various purposes of man-made abjects.(Sachari, 2002:5)

Desain adalah salah satu bentuk dorongan manusisa di bidang pengalaman, keahlian dan pengetahuan
Gorga Jurnal Seni Rupa

Volume 08 Nomor 02 Juli-Desember 2019

p-ISSN: 2301-5942 | e-ISSN: 2580-2380

terutama yang berhubungan dengan bentuk, komposisi, arti, nilai, dan berbagai benda buatan manusia.

Unsur desain merupakan bagian-bagian desain yang disusun untuk membentuk desain secara keseluruhan. Dalam sebuah karya desain masing-masing unsur tidak dapat dilepaskan satu sama lain meski terkadang sebuah karya desain tidak selamanya memuat unsur keseluruhan. Setiap unsur pembentuk desain akan memberikan konstribusi dari desain yang utuh.

Dapat disimpulkan bahwa desain ornamen merupakan unsur tambahan yang fungsinya sebagai penghias. Unsur-unsur desain bergantung pada jenis desainnya, dalam sebuah desain kerajinan secara visual setidaknya terdapat beberapa unsur pembentuk antara lain adanya titik, garis, bidang, warna, ornamen, dan tekstur.

\section{METODE PENELITIAN}

Metode penelitian yang digunakan dalam penelitian ini adalah penelitian korelasional (correlational research) penelitian yang melihat hubungan antara dua gejala (variabel). Penelitian ini adalah penelitian yang bertujuan mengetahui sejauh mana variabelvariabel berkaitan (berhubungan) berdasarkan koefisien korelasi.

Untuk mengumpulkan data dalam penelitian dilakukan dengan teknik tes. Sedangkan jenis tes yang dipakai adalah tes pengetahuan ornamen, kemampuan mendisain dan membatik motif ornamen Batak Angkola Mandailing.

\section{HASIL DAN PEMBAHASAN \\ 1.Hasil}

Sesuai dengan teknik pengumpulan data yang menggunakan teknik tes, yaitu tes pengetahuan ornamen dan kemampuan mendisain ornamen dengan hasil belajar membatik motif ornamen Batak Angkola Mandailing. Hasil tes pertama, kedua dan ketiga diobservasi oleh ketiga orang penilai dengan maksud untuk mendapatkan nilai sebagai data yang valid.

Berdasarkan hasil penilaian pengetahuan ornamen menunjukkan bahwa secara umum dalam pengetahuan ornamen siswa kelas X SMK Karya Bunda Medan berada pada kategori $\mathrm{B}$ (Baik), dengan jumlah nilai = 1601 dan nilai rata-rata $=84,3$.

Kemudian hasil penilaian kemampuan mendisain ornamen menunjukkan bahwa dalam kemampuan mendisain ornamen siswa kelas X SMK Karya Bunda 
Medan berada pada kategori B (Baik), dengan jumlah nilai $=1607$ dan nilai rata-rata $=84,6$.

Selanjutnya hasil penilaian belajar membatik motif ornamen Batak Angkola Mandailing menunjukkan bahwa dalam membatik motif ornamen Batak Angkola Mandailing siswa kelas X SM Karya Bunda Medan berada pada kategori B (Baik), dengan jumlah nilai $=1672$ dan nilai rata-rata $=87,9$.

\section{Pembahasan}

Berdasarkan data yang dikumpulkan dengan tes pengetahuan dan tes kemampuan yaitu pengetahuan ornamen, kemampuan mendisain ornamen, dan hasil belajar membatik motif ornamen Bataka Angkola Mandailing, setelah dinilai dan diperoleh data pengetahuan ornamen $\left(\mathrm{X}_{1}\right)$, kemampuan mendisain ornamen $\left(\mathrm{X}_{2}\right)$ dan membatik motif ornamen Batak Angkola Mandailing $(\bar{y})$, kemudian dianalisis dan diperoleh hasil sebagai berikut:

\section{1). Uji Normalitas}

Tabel.1 Hasil Analisis Uji Normalitas

\begin{tabular}{|l|c|c|c|c|}
\hline \multicolumn{1}{|c|}{ Variabel } & $\mathbf{N}$ & $\mathbf{L}_{\text {Hitung }}$ & $\mathbf{L}_{\text {tabel }}$ & Ket \\
\hline $\begin{array}{l}\text { Pengetahuan } \\
\text { Ornamen }\end{array}$ & 19 & 0,0594 & 0,195 & Normal \\
\hline $\begin{array}{l}\text { Mendisain } \\
\text { Ornamen }\end{array}$ & 19 & 0,0384 & 0,195 & Normal \\
\hline $\begin{array}{l}\text { Membatik Motif } \\
\text { Ornamen Batak } \\
\text { Angkola } \\
\text { Mandailing }\end{array}$ & 19 & 0,0307 & 0,195 & Normal \\
\hline
\end{tabular}

Berdasarkan tabel di atas maka diketahui bahwa data hasil pengetahuan ornamnen berdistribusi normal yang dibuktikan dengan uji normalitas dimana nilai $L_{\text {hitung }}$ $0,0594<L_{\text {tabel }} 0,195$. Selanjutnya untuk data hasil mendisain ornamen juga berdistribusi normal dengan nilai $L_{\text {hitung }} 0,0384<L_{\text {tabel }} 0,195$. Kemudian untuk data hasil belajar membatik motif ornamen Batak Angkola Mandailing berdistribusi normal dengan nilai $L_{h i t u n g}$ $0,0307<L_{\text {tabel }}$ 0,195. Berdasarkan keterangan pada tabel di atas dapat disimpulkan bahwa ketiga data variabel penelitian berdistribusi normal.

\section{2).Uji Linieritas}

Tabel .2 Rangkuman Uji Linieritas Antara $\mathrm{X}_{1}, \mathrm{X}_{2}$ Dengan $\mathrm{Y}$

\begin{tabular}{|c|c|c|c|c|c|}
\hline $\mathbf{N}$ & $\mathbf{k}$ & $\boldsymbol{J K}_{\text {regresi }}$ & $\boldsymbol{J K}_{\text {resensi }}$ & $\mathbf{F}$ & $\begin{array}{c}\mathbf{F}_{\text {tabel }} \\
\text { hitung }\end{array}$ \\
$\begin{array}{c}\boldsymbol{\alpha}= \\
\mathbf{0 , 0 5}\end{array}$ \\
\hline 19 & 2 & 3259082,272 & 3124497 & 8,34 & 3,63 \\
\hline
\end{tabular}

Gorga Jurnal Seni Rupa

Volume 08 Nomor 02 Juli-Desember 2019 p-ISSN: 2301-5942 | e-ISSN: 2580-2380

Berdasarkan tabel diatas diperoleh bahwa $F_{\text {tabel }}$ dengan Dk (2:16) pada $\alpha=0,05$ adalah 3,63 sedangkan $F_{\text {hitung }}$ diperoleh sebesar8,34 dan ternyata $F_{\text {hitung }}>F_{\text {tabel }}$ sehingga persamaan regresi tersebut adalah linier.Dengan demikian dapat disimpulkan bahwa persamaan regresi $\widehat{Y}=23,9+0,002 x_{1}+$ $0,705 x_{2}$ mempunyai hubungan yang linier dan signifikan pada taraf kepercayaan $\alpha=0,05$.

\section{3). Analisis Korelasi}

Besar hubungan antara pengetahuan ornamen dengan hasil belajar membatik motif ornamen Batak Angkola Mandailing, besar hubungan diperoleh $r_{\text {hitung }}=0,60$ berkriteriakorelasi sedang. Bila menggunakan kriteria tabel product moment maka untuk taraf nyata $\alpha=0,05$ dengan $\mathrm{n}=19$ kriterianya adalah 0,195 harga $\mathrm{r}$ yang peroleh melebihi kriteria ( $r_{\text {hitung }}>r_{\text {tabel }}$ ) dan tentunya berkorelasi sedang, dengan demikian dapat diartikan bahwa variabel $X_{1}$ dan $\mathrm{Y}$ memiliki hubungan yang kuat.

Besar hubungan antara kemampuan mendisain ornamen dengan hasil belajar membatik motif ornamen Batak Angkola Mandailing, besar hubungan diperoleh $\mathrm{r}_{\text {hitung }}=0,58$ berkriteria sedang. Bila menggunakan kriteria tabel product moment maka untuk taraf nyata $\alpha=0,05$ dengan $\mathrm{n}=19$ kriterianya adalah 0,195, harga $\mathrm{r}$ yang peroleh melebihi kriteria ( $r_{\text {hitung }}>r_{\text {tabel }}$ ) dan tentunya berkorelasi sedang, dengan demikian dapat diartikan bahwa variabel $X_{2}$ dan $\mathrm{Y}$ juga memiliki hubungan yang kuat.

Selanjutnya besar hubungan antara pengetahuan ornamen dengan kemampuan mendisain ornamen, besar hubungan diperoleh $\mathrm{r}_{\text {hitung }}=0,75$ berkriteria sedang. Bila menggunakan kriteria tabel product moment maka untuk taraf nyata $\alpha=0,05$ dengan $\mathrm{n}=$ 19 kriterianya adalah 0,195 , harga $r$ yang peroleh melebihi kriteria $\left(r_{\text {hitung }}>r_{\text {tabel }}\right)$ dan tentunya berkorelasi sedang, dengan demikian dapat diartikan bahwa variabel $X_{1}$ dan $X_{2}$ juga memiliki hubungan yang kuat.

Besar sumbangan (kontribusi) antara pengetahuan ornamen dengan hasil belajar membatik motif ornamen batak Angkola Mandailing diperoleh r2= $60 \%$ artinya bahwapengetahuan ornamen (X_1) memberi kontribusi atau masukan (sumbangan) pada hasil belajar membatik motif ornamen batak Angkola Mandailing (Y) rata-rata $60 \%$, sisanya $40 \%$ dari variabel lain.

Selanjutnya besar sumbangan (kontribusi) antara kemampuan mendisain ornmen dengan hasil belajar membatik motif ornamen Batak Angkola Mandailing diperoleh $\mathrm{r} 2=58 \%$ artinya bahwa kemampuan 
mendisain ornamen (X_2) memberi kontribusi atau masukan (sumbangan) pada hasil belajar membatik motif ornamen batak Angkola Mandailing (Y) ratarata $58 \%$, sisanya $42 \%$ dari variabel lain.

Selanjutnya besar sumbangan (kontribusi) antara pengetahuan ornamen dengan kemampuan mendisain ornmen diperoleh $\mathrm{r} 2=75 \%$ artinya bahwa kemampuan mendisain ornamen (X_1) memberi kontribusi atau masukan (sumbangan) pada hasil kemampuan mendisain ornmen (X_2)rata-rata $75 \%$, sisanya $25 \%$ dari variabel lain.

\section{4). Uji Signifikan}

Signifikasi hubungan antara pengetahuan dan kemampuan mendisain ornamen dengan hasil belajar membatik motif ornamen Batak Angkola Mandailing di peroleh $t_{\text {hitung }}=8,34$ untuk $D k=n-2=17 \alpha=0,05 t_{\text {tabel }}$ $=1,697$ ternyata $t_{\text {hitung }}>t_{\text {tabel }}(8,34>1,697)$, artinya antara variabel $X_{1}, X_{2}$ dengan $\mathrm{Y}$ memiliki hubungan yang sangat signifikan atau yang berarti, antara pengetahuan $\left(X_{1}\right)$ dan kemampuan mendisain ornamen $\left(X_{2}\right)$ dengan hasil belajar membatik motif ornamen Batak Angkola Mandailing (Y).

\section{5). Uji Hipotesis}

Berdasarkan hasil perhitungan uji hipotesis diperoleh besar hubungan antara pengetahuan dan kemampuan mendisain ornamen dengan hasil belajar membatik motif ornamen Batak Angkola, besar hubungan diperoleh $r_{\text {hitung }}=4,87$ berkriteriakorelasi kuat. Bila menggunakan kriteria tabel product moment maka untuk taraf nyata $\alpha=0,05$ dengan $\mathrm{n}=19$ kriterianya adalah 3,63, harga $r$ yang peroleh melebihi kriteria $\left(r_{\text {hitung }}>r_{\text {tabel }}\right)$ dan tentunya berkorelasi kuat, dengan demikian dapat diartikan bahwa variabel $\left(X_{1}\right)$ dan $\left(X_{2}\right)$ dengan $\mathrm{Y}$ memiliki hubungan yang kuat.

Besar sumbangan (kontribusi) antara pengetahuan dan kemampuan mendisain ornamen dengan hasil belajar membatik motif ornamen batak Angkola Mandailing diperoleh $r^{2}=62 \%$ artinya bahwa pengetahuan $\left(X_{1}\right)$ dan kemampuan mendisain ornamen $\left(X_{2}\right)$ memberi kontribusi atau masukan (sumbangan) pada hasil belajar membatik motif ornamen Batak Angkola Mandailing (Y) rata-rata 62\%, sisanya 38\% dari variabel lain.

Signifikasi hubungan antara pengetahuan dan kemampuan mendisain ornamen dengan hasil belajar membatik motif ornamen Batak Angkola Mandailing di peroleh $\mathrm{t}_{\text {hitung }}=8,34$ untuk $\mathrm{Dk}=\mathrm{n}-2=17 \alpha=0,05 \mathrm{t}_{\text {tabel }}$ $=1,697$ ternyata $t_{\text {hitung }}>t_{\text {tabel }}(8,34>1,697)$, artinya antara variabel $X_{1}, X_{2}$ dengan $\mathrm{Y}$ memiliki hubungan yang sangat signifikan atau yang berarti, antara pengetahuan $\left(X_{1}\right)$ dan kemampuan mendisain ornamen $\left(X_{2}\right)$ dengan hasil belajar membatik motif ornamen Batak Angkola Mandailing (Y).

Dengan demikian hipotesis $\mathrm{Ho}=0$ yang berbunyi diduga tidak ada hubungan yang signifikan antara pengetahuan dan kemampuan mendisain ornamen dengan hasil belajar membatik motif ornamen Batak Angkola Mandailing ditolak, dan $\mathrm{Ha} \neq 0$ yang berbunyi diduga ada hubungan yang signifikan antara antara pengetahuan dan kemampuan mendisain ornamen dengan hasil belajar membatik motif ornamen Batak Angkola Mandailing diterima.

Dari penjelasan di atas dapat disimpulkan bahwa terdapat hubungan yang signifikan antara pengetahuan dan kemampuan mendisain ornamen dengan hasil belajar membatik motif ornamen Batak Angkola Mandailing.

\section{KESIMPULAN DAN SARAN \\ 1.Kesimpulan}

Terdapat hubungan yang signifikan antara pengetahuan dan kemampuan mendisain ornamen dengan hasil belajar membatik motif ornamen Batak Angkola Mandailing. Besar sumbangan (kontribusi) antara pengetahuan dan kemampuan mendisain ornamen dengan hasil belajar membatik motif ornamen batak Angkola Mandailing yaitu sebesar $62 \%$ sehingga sumbangan pengetahuan dan kemampuan mendisain ornamen terhadap hasil belajar membatik motif ornamen Batak Angkola Mandailing memberikan dampak yang positif. $38 \%$, dipengaruhi faktor lain seperti alat dan bahan yang digunakan siswa, tingkat kemahiran , pengalaman siswa dalam membuat batik, motivasi esternal dan internal. Besar hubungan antara pengetahuan dan kemampuan mendisain ornamen terhadap hasil belajar membatik motif ornamen Batak Angkola Mandailing berkorelasi yaitu 0,62 .

\section{Saran}

Dalam upaya meningkatkan kemampuan siswa dalam kegiatan belajar membatik motif ornamen Bataka Angkola Mandailing:

Pihak SMK Karya Bunda Medan perlu untuk mengkaji lagi tentang perlunya meningkatkan pengetahuan dan kemampuan siswa dalam mendisain ornamen memberi waktu tersendiri dalam kegiatan belajar membatik. Pada guru bidang studi muatan lokal sebaiknya dapat menambah pengetahuan dan kemampuan yang lebih dalam lagi tenggang pengetahuan dan kemampuan mendisain ornamen, dengan tujuan agar pengetahuan dan kemampuan 
mendisain ornamen yang dimiliki akan memberikan masukan yang lebih dalam menunjang kemampuan siswa dalam belajar mendisain ornamen dan membatik motif ornamen Batak Angkola Mandailing yang lebih baik. Pada siswa agar dapat mengkaji kembali pentingnya memiliki pengetahuan dan kemampuan mendisain ornamen yang baik dalam proses belajar membatik motif ornamen Batak Angkola Mandailing.

\section{DAFTAR RUJUKAN}

Hamalik, Oemar ( 2013). Dasar-Dasar

Pengembangan Kurikulum. Bandung: Remaja Rosdakarya.

Ratnawati, dkk (2006). Strategi Hasil Belajar dan Faktor-Faktor Yang Mempengaruhi. Jakarta: C.V. Aneka Ilmu.

Sachari, Agus, dan Sunarya, Yan, Yan. (2002). Sejarah dan Perkembangan Desain \& Dunia Kesenirupaan di Indonesia. Bandung: ITB.

Sardiman. A.M (2010). Interaksi dan Motivasi Belajar Mengajar. Jakarta: Rajawali Pers.

(2009). Interaksi dan Motivasi Belajar Mengajar. Jakarta: Rajawali Pers.

Sirait, Baginda (1980). Laporan Penelitian Pengumpulan Dan Dokumentasi Ornamen Tradisional Di Sumatera Utara. Medan: IKIP.

Slameto. (2010). Belajar dan Faktor-faktor Yang Mempengaruhinya. Jakarta: Rineka Cipta.

Sudjana. Nana (2014). Penilai Hasil Proses Belajar Mengajar. Bandung: Remaja Rosdakarya.

Soepratno. (1997). Ornamen Ukir Kayu Tradisional Jawa. Semarang: PT. Effhar. 